\title{
DETERMINAN KARAKTERISTIK KONTEN DAN PENGARUHNYA TERHADAP PENERIMAAN PENGGUNA PADA APLIKASI TRAVELATION
}

\section{DETERMINANTS OF CONTENT CHARACTERISTICS AND ITS EFFECT ON USER ACCEPTANCE OF THE TRAVELATION APPLICATION}

\author{
Muhamad Isnaini ${ }^{1}$, Rustono Farady Marta ${ }^{1}$, Lieta Septiarysa ${ }^{2}$, Vincent Atmaja ${ }^{2}$, Michelle ${ }^{2}$ \\ ${ }^{1}$ Program Studi Magister Ilmu Komunikasi Universitas Bunda Mulia, Jakarta \\ ${ }^{2}$ Mahasiswa Program Studi Magister Ilmu Komunikasi Universitas Bunda Mulia, Jakarta \\ Jln. Lodan Raya No. 2 Anco, Jakarta Utara, Jakarta, Indonesia. \\ ${ }^{1} 11901 @$ lecturer.ubm.ac.id
}

Diterima tgl. 07/05/2021; Direvisi tgl. 15/12/2021; Disetujui tgl. 17/12/2021

\begin{abstract}
In the pandemic situation, innovation is a necessity for companies. This also applies to companies engaged in airport services. The Travelation application is an innovation of PT. Angkasa Pura 2, which was developed with the aim of facilitating travel management. The purpose of this study is to analyze the effect of content characteristics with user acceptance on the Travelation application. The research uses a quantitative approach, with an online survey method. The results showed that the five characteristics of the content, namely benefit, suitability, complexity, observability, and data accuracy, were well received by users. Users also feel that the Travelation application provides benefits so that they accept the presence of the web-based application. Hypothesis testing proves that there is an influence between content characteristics and user acceptance. For improvement, the Travelation application is expected to update information and improve data accuracy.
\end{abstract}

Keywords: application/apps, content, technology acceptance, Travelation

\begin{abstract}
ABSTRAK
Inovasi selama pandemi adalah sebuah keharusan bagi perusahaan. Hal ini juga berlaku bagi perusahaan yang bergerak di bidang jasa kebandarudaraan. Aplikasi Travelation merupakan inovasi PT. Angkasa Pura 2, yang dikembangkan dengan tujuan untuk memudahkan pengurusan perjalanan. Tujuan penelitian ini adalah untuk menganlisis pengaruh karakteristik konten dengan penerimaan pengguna pada aplikasi Travelation. Penelitian menggunakan pendekatan kuantitatif, dengan metode survei online. Hasil penelitian menunjukkan, dari kelima karakteristik konten, yakni keuntungan, kesesuaian, kerumitan, observabilitas, dan akurasi data, dapat diterima dengan baik oleh pengguna. Pengguna juga merasa bahwa aplikasi Travelation memberikan manfaat sehingga menerima kehadiran aplikasi berbasis web itu. Pengujian hipotesis membuktikan, terdapat pengaruh antara karakteristik konten dengan penerimaan pengguna. Untuk perbaikan, aplikasi Travelation diharapkan memperbarui informasi serta meningkatkan keakuratan data.
\end{abstract}

Kata Kunci: Aplikasi/apps, konten, penerimaan teknologi, Travelation

\section{PENDAHULUAN}

Perkembangan aplikasi berbasis teknologi informasi (apps), baik untuk platform telepon pintar (smartphone) maupun komputer jinjing (laptop/tablet) semakin maju (Briz-Ponce \& GarcíaPeñalvo, 2015). Menurut (Kim (Sunny), 2016), faktor pendukung perkembangan aplikasi antara lain semakin meningkatnya pengguna perangkat bergerak (mobile device). Selain itu, menjamurnya telepon pintar, laptop, dan tablet, semakin meningkatkan ekspektasi konsumen digital atas sebuah aplikasi. Cho et al., (2020) mengemukakan bahwa aplikasi memiliki beragam kategori, misalnya game, bisnis, pendidikan, gaya hidup, hiburan, dan perjalanan. Tujuannya antara lain sebagai sarana pencarian informasi, jual beli barang, atau panduan ketika melakukan perjalanan. 
Munculnya beragam aplikasi di toko aplikasi (app store) yang terpasang di telepon pintar dan komputer jinjing membuat perusahaan pengembang (app developer) semakin giat membuat aplikasi untuk memudahkan masyarakat. Kamel Boulos et al., (2014), mendefinisikan aplikasi sebagai perangkat lunak yang dikembangkan untuk tujuan tertentu dan biasanya dioptimalkan untuk dioperasikan di perangkat seluler, sementara menurut Byun et al., (2018), aplikasi pada umumnya dirancang untuk memberikan sarana yang nyaman bagi pengguna dalam melakukan tugas-tugas tertentu.

Hal yang tidak dapat dipisahkan dari hadirnya bermacam aplikasi adalah pertaliannya dengan perkembangan e-commerce serta penetrasi internet di Indonesia yang terus meningkat. Survei yang dilakukan oleh Asosiasi Penyelenggara Jaringan Internet Indonesia (APJII) mengungkap bahwa sepanjang 2020, sebanyak 196,7 juta orang Indonesia telah terhubung ke internet, dari total 270,2 juta penduduk. Penyebab meningkatnya penetrasi internet tersebut adalah perkembangan infrastruktur dan mudahnya mendapatkan perangkat bergerak (APJII, 2020). Survei tersebut juga mengungkapkan perangkat yang digunakan untuk mengakses internet, yakni: 1) sebanyak 95,4\% mengakses melalui perangkat telepon pintar; 2) Sejumlah 19,7\% mengakses dari komputer jinjing; dan 3) sebanyak 9,5\% mengakses hanya dari komputer pribadi/PC.

Pengembangan suatu aplikasi bukannya tanpa masalah. Selalu muncul potensi risiko atas aplikasi, sebagaimana dikemukakan Priyono (2017). Meskipun demikian, risiko tersebut menjadi modal dasar, apakah aplikasi tersebut diterima atau ditolak masyarakat. Ispriandina \& Sutisna (2019) mengemukakan, keberlanjutan aplikasi perlu mempertimbangkan faktor kebiasaan, pengaruh sosial, dan motivasi pengguna, sementara intensi menggunakan aplikasi dipengaruhi kebiasaan, pengaruh sosial, motivasi, serta dukungan dan sumberdaya konsumen. Bagi Mugo et al., (2017) penerimaan aplikasi adalah pondasi dalam proses mencerdaskan masyarakat yang dipengaruhi oleh faktor persepsi atas kegunaan aplikasi, kemudahan digunakan, dan sikap terhadap penggunaan. Selain itu, faktor eksternal, seperti kebiasaan, pengaruh sosial, motivasi, risiko dan kepercayaan, serta persepsi atas kegunaan aplikasi juga menjadi dasar penerimaan aplikasi tersebut. Menurut Kim \& Kim (2020), selain faktor eksternal, faktor internal dari aplikasi itu sendiri, misalnya konten, juga memperngaruhi penerimaan atas suatu aplikasi. Hal yang sama juga dikemukakan Dastjerdi et al., (2019) yang mengemukakan perlunya memasukan karateristik konten sebagai salah satu parameter penerimaan terhadap suatru aplikasi.

Salah satu jenis aplikasi yang pengembangannya paling pesat adalah aplikasi untuk perjalalan (travel apps) (Dickinson et al., 2015). Menurut S.-J. Lee \& Jing (2015), perusahaan pariwisata dan afiliasi yang terkait seperti bisnis transportasi dan perhotelan mulai mengadopsi aplikasi perjalanan. Tujuannya adalah untuk meningkatkan pengenalan merek dan volume penjualan jasa pariwisata. Hal ini juga didukung oleh fakta bahwa intensi untuk menggunakan aplikasi oleh orang-orang yang akan melakukan perjalanan ternyata cukup tinggi (Wu \& Lee, 2017).

Kondisi pandemi yang mengharuskan masyarakat mengikuti aturan untuk membatasi interaksi menjadi salah satu alasan PT. Angkasa Pura II meluncurkan aplikasi berbasis situs web untuk membantu perjalanan menggunakan transportasi udara. Aplikasi dengan nama "Travelation" tersebut yang telah diuji coba pada bulan Juni 2020 dan telah diterapkan sebagai aplikasi pengecekan secara digital terhadap dokumen-dokumen yang dipersyaratkan bagi pelaku perjalanan untuk dapat melakukan penerbangan. Dengan adanya aplikasi tersebut, masyarakat dapat memenuhi seluruh dokumen persyaratan penerbangan dan mengumpulkannya dalam satu aplikasi, sehingga dapat lebih mudah untuk divalidasi oleh petugas yang berwenang di bandar udara keberangkatan.

Meskipun saat ini aplikasi merupakan hal yang lumrah dan dapat ditemukan di semua perangkat pintar (telepon, komputer jinjing) (Hassan et al., 2014), bukan berarti masyarakat dapat 
begitu saja menerima sebuah aplikasi. Sebagaimana dikemukakan Taherdoost (2018), penerimaan pada suatu aplikasi dapat dianalogikan dengan proses adopsi inovasi. Rogers (1995) menyatakan adopsi adalah proses untuk mengambil keputusan menerima atau menolak ide/inovasi baru. Terminologi adopsi biasanya dilekatkan dengan inovasi dan difusi. Dengan kata lain, inovasi harus didifusikan. Difusi biasanya terjadi pada tingkat yang lebih luas, seperti pada masyakarat, sedangkan adopsi secara umum terjadi pada unit yang lebih kecil, seperti perusahaan dan individu. Rogers (1995) mendefinisikan difusi sebagai "the process by which an innovation is communicated through certain channels over time among the members of a social system". Menurut Rogers (1995) kecepatan difusi sebuah inovasi dipengaruhi oleh empat elemen, yaitu (1) karakteristik inovasi; (2) kanal komunikasi yang digunakan untuk mengkomunikasi manfaat inovasi; (3) waktu sejak inovasi diperkenalkan; dan (4) sistem sosial tempat inovasi berdifusi. Semakin besar dan rumit inovasi, semakin lama waktu yang dibutuhkan dalam difusi.

Rogers (1995) membedakan orang yang mengadopsi inovasi berdasar waktu, yakni: early adopters, early majority, late majority, dan laggard. Jumlah kumulatif orang yang mengadopsi inovasi awalnya sedikit, kemudian naik dengan cepat dan akhirnya mencapai kondisi stagnan. Terkait dengan sistem sosial, sebuah inovasi akan berdifusi dengan cepat pada sistem sosial yang homogen. Potensi mengadopsi sebuah inovasi serta kemungkinan meningkatnya adopsi akan dipengaruhi inovasi itu sendiri, yakni jika inovasi tersebut: (1) menjanjikan keuntungan yang lebih baik dari pada yang menjadi alternatif; (2) kompatibel/sesuai dengan praktik yang telah dilakukan; (3) sederhana; dan (4) jika inovasi tersebut dapat diujicobakan dan hasilnya dapat diamati. Pilihan untuk mengadopsi inovasi akan bermuara pada pelaksanaan uji coba inovasi. Hasil positif dari uji coba tersebut akan berujung pada penggunaan dan institusionalisasi inovasi oleh organisasi yang mengadopsi, sementara hasil negatif berdampak pada penolakan inovasi (Rogers, 1995).

Mengacu pada pemikiran Fishbein dan Ajzen tentang Theory Reasoned Action, Davis (Chuttur, 2009) mengemukakan bahwa penerimaan teknologi atau motivasi pengguna untuk memanfaatkan teknologi dipengaruhi tiga faktor: persepsi atas kemudahan penggunaan, persepsi kegunaan, dan perilaku terhadap sistem. Selain faktor-faktor tersebut, Marangunić \& Granić, (2015) menawarkan determinan lain dalam konteks penerimaan teknologi, yakni kemampuan kognitif sebagai bagian karakteristik individu; gender dan perbedaan budaya, yang didalamnya mencakup emosi, kebiasaan, perbedaan individu, dan perubahan teknologi; kepuasaan atau performa dari aplikasi/teknologi.

Sejumlah penelitian berhasil mengungkap penerimaan pengguna pada aplikasi. Priyono (2017) yang meneliti dompet elektronik (e-wallet) Go-Pay menemukan faktor risiko dan kepercayaan sebagai penentu penerimaan teknologi. Kemudian, Ispriandina \& Sutisna (2019) yang meneliti intensi kontinuitas penggunaan dompet elektronik dan menemukan faktor pendukung intensi tersebut, yakni kebiasaan, pengaruh sosial, dan motivasi hedonik. Penelitian Mugo et al., (2017) di Kenya menyelidiki tentang utilisasi mobile learning yang dipengaruhi oleh persepsi terhadap kegunaan aplikasi. Penelitian lain, misalnya oleh Nugroho et al., (2017) menemukan bahwa persepsi atas kemudahan aplikasi dan kegunaan menjadi pertimbangan penting bagi konsumen dalam memilih dan mengadopsi aplikasi Traveloka. Hasi penelitian ini serupa dengan yang dilakukan oleh Mugo et al., (2017).

Dengan sampel pelajar SMA, Primawati (2015) meneliti tentang kesiapan menggunakan aplikasi Google Docs. Hasil penelitian menunjukkan, kemampuan dan adaptasi pelajar terhadap komputer dan variabel kesiapan yaitu optimis dan inovasi berpengaruh secara signifikan terhadap penerimaan aplikasi Google Docs. Hal yang sama juga dilakukan oleh Yulistyanti (2016) dan menemukan bahwa penerimaan siswa terhadap aplikasi Dropbox dipengaruhi oleh karakteristik demograsi, terumata jenis kelamin dan tingkat pendidikan. 
Penerimaan dan pemanfaatan teknologi juga menjadi perhatian di kalangan koperasi dan pelaku usaha kecil-menengah (UMKM). Penelitian yang dilakukan oleh Sugiharto et al., (2007) misalnya, menunjukkan bahwa tingkat adopsi teknologi internet memiliki potensi besar dalam meningkatkan kinerja perusahaan. Pelaku usaha yang tergolong ke dalam pengadopsi internet (internet adopter) berpotensi memiliki usaha yang lebih baik kinerjanya dibandingan dengan pelaku usaha kecil, baik yang bukan pengadopsi internet (internet non-adopter) maupun yang tertarik atau berencana untuk menjadi pengadopsi internet (potential internet adopter). Hal tersebut dibuktikan Utomo \& Jumali, (2021) yang menemukan bahwa persepsi atas kegunaan menjadi faktor yang menentukan penerimaan aplikasi pemasaran pada anggota koperasi perempuan. Di kalangan petani, penelitian oleh Karomah (2020) menunjukkan bahwa petani dapat menerima aplikasi RegoPantes yang digunakan sebagai sarana pemasaran hasil panel dengan faktor utama pada tingkat pendidikan, akses informasi, dan harapan atas aplikasi tersebut.

Khusus untuk aplikasi yang membantu perjalanan, penelitian Lu et al., (2015) menemukan, determinan paling signifikan dalam penerimaan aplikasi perjalanan terletak pada persepsi kegunaan, persepsi atas kemudahan digunakan, dan kompatibilitas. Hal ini sejalan dengan penelitian Mugo et al., (2017). Gupta et al., (2018) menemukan bahwa faktor signifikan pengguna untuk menerima aplikasi perjalanan adalah ekspektasi atas performa aplikasi tersebut, pengaruh sosial, persepsi risiko, kepercayaan, dan kebiasaan pemakaian aplikasi sebelumnya. Selain itu, penerimaan khalayak dipengaruhi oleh anteseden kualitas informasi dan kualitas layanan aplikasi (Ali et al., 2021).Bagi Dastjerdi et al., (2019), efisiensi, interaksi sosial, kenikmatan, serta konten yang bersisi promosi perjalanan yang ramah lingkungan adalah alasan untuk menerima suatu aplikasi baru.

Mengacu pada konsep-konsep penelitian sebagaimana dijelaskan di atas serta kesenjangan penelitian, yakni belum ada penelitian yang mengkaji aspek internal aplikasi, misalnya karakteristik konten, maka dapat dibuat bagan kerangka pikir penelitian sebagai berikut:

Ditolak

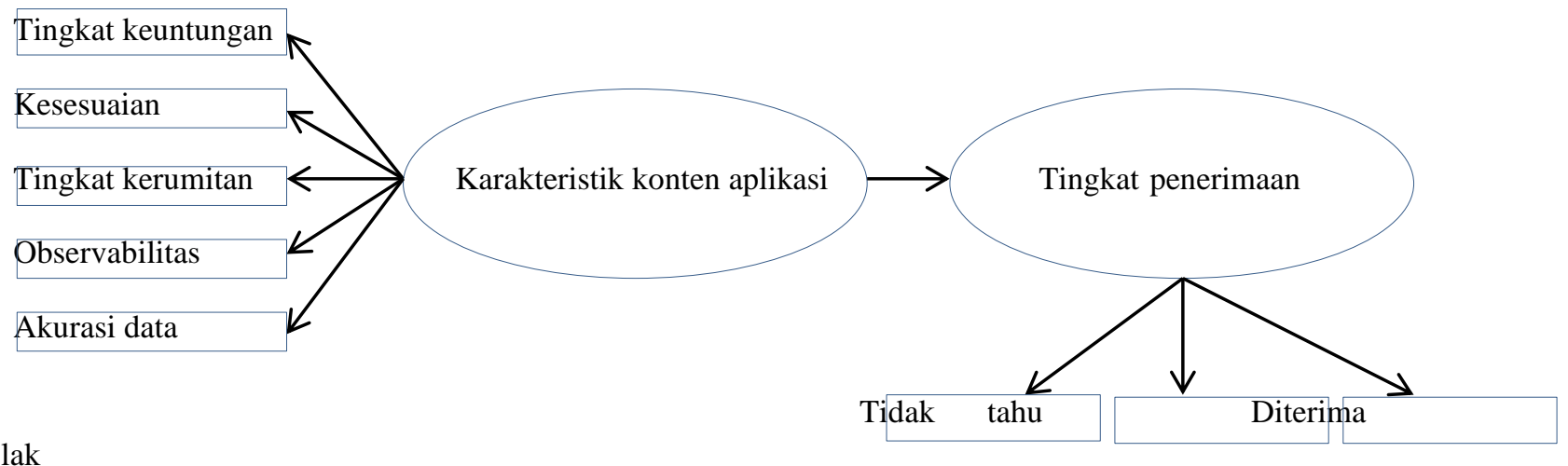

Gambar 1. Kerangka pikir penelitian

Berdasarkan kerangka pikir sebagaimana gambar di atas, maka hipotesis yang dibangun adalah terdapat pengaruh antara karakteristik konten terhadap penerimaan pengguna pada aplikasi Travelation. Dengan demikian, tujuan penelitian ini adalah untuk menganalisis sejauh mana karakteristik konten mempengaruhi penerimaan pengguna pada aplikasi Travelation. 


\section{METODE PENELITIAN}

Penelitian ini menggunakan paradigma yang dibangun berdasarkan filsafat positivisme. Konsekuensinya, pendekatan yang dipakai adalah kuantitatif. Beberapa ciri khas dari pendekatan kuantitatif ialah: bersandar pada pengumpulan data dan analisis data kuantitatif (numerik), menggunakan strategi survei dan eksperimen, mengadakan pengukuran dan observasi, serta melaksanakan pengujian hipotesis yang dibuat dengan serangkaian uji statistik (Park et al., 2020).

Metode yang digunakan dalam penelitian ini adalah survei online, dilakukan pada periode Januari-Februari 2021. Populasi target penelitan ini adalah kumulatif masyarakat yang menjadi pengikut (follower) akun PT Angkasa Pura II melalui dua platform media sosial, yakni Instagram dan Twitter, yakni sebanyak 220.800 orang. Kuesioner dibuat menggunakan Google Forms dan disebarluaskan melalui Direct Message (DM) ke para pengikut tersebut. Pemilihan sampel dilakukan secara acak sederhana, dengan target sebanyak 100 responden, yakni sesuai dengan perhitungan menggunakan rumus Slovin dengan taraf ketelitian (e) 10\%, sebagai berikut:

$$
\mathrm{n}=\frac{\mathrm{N}}{1+\mathrm{Ne}^{2}}=\frac{220.800}{1+220.800 .(0.01)}=\frac{220.800}{2209}=99.95 \text { (dibulatkan 100) }
$$

Pada akhir masa pengisian kuesioner, terkumpul jawaban dari 72 responden. Data dari 72 responden itulah yang kemudian dipakai dalam penelitian ini.

Instrumen dalam penelitian ini adalah kuesioner dengan pertanyaan tertutup menggunakan skala Likert. Terdapat tiga bagian besar pertanyaan, yakni tentang karakteristik responden, karakteristik konten teknologi aplikasi, dan penerimaan atas aplikasi. Indikator untuk karakteristik konten teknologi diadaptasi dari Govender (2013) yang meliputi keuntungan, kesesuaian, kerumitan, observabilitas, dan tingkat akurasi data. Data yang diperoleh melalui Google Form kemudian dipindahkan ke Microsoft Excel, untuk dilakukan pengkodean. Data yang tersaji di Microsoft Excel kemudian diekspor ke perangkat lunak SPSS 23 untuk diolah dan dianalisis. Data berbentuk angka disajikan dalam bentuk tabel dan grafik yang disertai dengan interpretasi berdasarkan persentase dan nilai rata-rata. Pengujian validitas dan hipotesis menggunakan korelasi Pearson, sementara reliabilitas berpatokan pada nilai alfa Cronbach.

\section{HASIL DAN PEMBAHASAN}

\subsection{Hasil Penelitian}

Karakteristik demografi responden dibagi berdasarkan jenis kelamin, usia, domisili/tempat tinggal, tingkat pendidikan, dan pekerjaan. Selengkapnya disajikan di tabel 1:

Tabel 1. Karakteristik demografi responden

\begin{tabular}{llll}
\hline Variabel & Kategori & Jumlah (orang) & Persentase (\%) \\
\hline Jenis kelamin & Laki-laki & 56 & 80.5 \\
\multirow{2}{*}{ Usia } & Perempuan & 16 & 19.5 \\
& $21-30$ & 12 & 16.66 \\
& $31-40$ & 15 & 20.83 \\
& $41-50$ & 31 & 43.05 \\
Domisili & $>50$ & 14 & 19.4 \\
& Jakarta & 45 & 62.5 \\
Tingkat pendidikan & Luar Jakarta & 27 & 37.5 \\
& SD (rendah) & 0 & 0 \\
& SMP-SMA (menengah) & 22 & 30.56 \\
& Diploma-S1/S2/S3 (tinggi) & 50 & 69.44
\end{tabular}




\begin{tabular}{lll} 
Pekerjaan & $\begin{array}{l}\text { Bekerja } \quad \text { PNS, swasta, } \\
\text { wirausaha, lain-lain) }\end{array}$ & 81.2 \\
Belum bekerja/mahasiswa & 14 & 18.8 \\
\hline Sumber: Olahan penelitian (2021)
\end{tabular}

Sumber: Olahan penelitian (2021)

Fakta bahwa jumlah responden perempuan sebesar $19.5 \%$ dan laki-laki, $80.5 \%$ atau dengan perbandingan $1: 7$ karena sebagian besar kaum laki-laki bekerja dengan mobilitas yang tinggi, sehingga membutuhkan alat transportasi yang memadai, sementara kaum perempuan yang bekerja jarang sekali memerlukan mobilitas yang tinggi. Hal tersebut ditambah basis empirik dari penelitian Styawan (2021) yang menunjukkan bahwa selama pandemi, mobilitas laki-laki cenderung lebih tinggi di luar rumah, sementara perempuan lebih banyak menghabiskan waktunya untuk melakukan pekerjaan-pekerjaan domestik di rumah.

Gambaran umum responden juga dapat dilihat dari usia responden. Survei menunjukkan bahwa rata-rata usia responden yang paling tinggi yaitu pada usia 41-50 tahun yaitu 43,05\% atau 31 orang dari jumlah responden. Hal ini mengindikasikan bahwa sebagian besar responden masih produktif. Usia produktif seseorang berkisar antara usia 15-64 tahun karena pada usia tersebut dianggap mampu menghasilkan barang maupun jasa dalam proses produksi. Dari sisi domisili, sebagian besar responden (62.5\%) berdomisili di Jakarta, sementara sisanya (37.5\%) di luar Jakarta. Hal ini menunjukkan masih dominannya Jakarta sebagai tempat mobilitas penduduk dibandingkan kota-kota lain di Indonesia.

Tingkat pendidikan responden mengerucut menjadi dua kategori yaitu pendidikan menengah (SMP dan SMA), dan pendidikan tinggi (Diploma, S1-S3). Berdasarkan tabel 1 di atas, menunjukkan bahwa sebagian besar responden mempunyai tingkat pendidikan tinggi $(69.44 \%)$, sementara sisanya (30.56) berpendidikan SMA atau yang sederajat dan SMK. Tingkat pendidikan ini setidaknya mempengaruhi kapasitas responden dalam menganalisis konten yang tersedia di aplikasi Travelation.

Dari sisi pekerjaan, mayoritas responden $(81.2 \%)$ adalah bekerja, yakni sebagai swasta, PNS, wirausaha, dan lain-lainnya. Sisanya $(18.8 \%)$ masih belum mendapat pekerjaan atau berstatus sebagai mahasiswa. Hal ini menunjukkan bahwa sebagian besar pengguna aplikasi Travelation adalah orang-orang yang benar-benar telah bekerja dan membutuhkan aplikasi tersebut untuk menunjang aktivitas mereka dalam melakukan perjalanan.

Variabel karakteristik konten aplikasi Travelation dicerminkan oleh lima indikator yaitu tingkat keuntungan, kesesuaian informasi, tingkat kerumitan, observabilitas (kemudahan untuk dilihat dan dikomunikasikan kepada orang lain), dan akurasi data. Hasil survei menunjukkan bahwa sebagian besar responden menyatakan Travelation menguntungkan dan sangat menguntungkan (30.5\% dan 40.3\%). Responden mengungkapkan bahwa dengan adanya Travelation, pengguna dapat menentukan keperluan dokumen terbang. Grafik hasil survei dapat dilihat pada Gambar 1. 


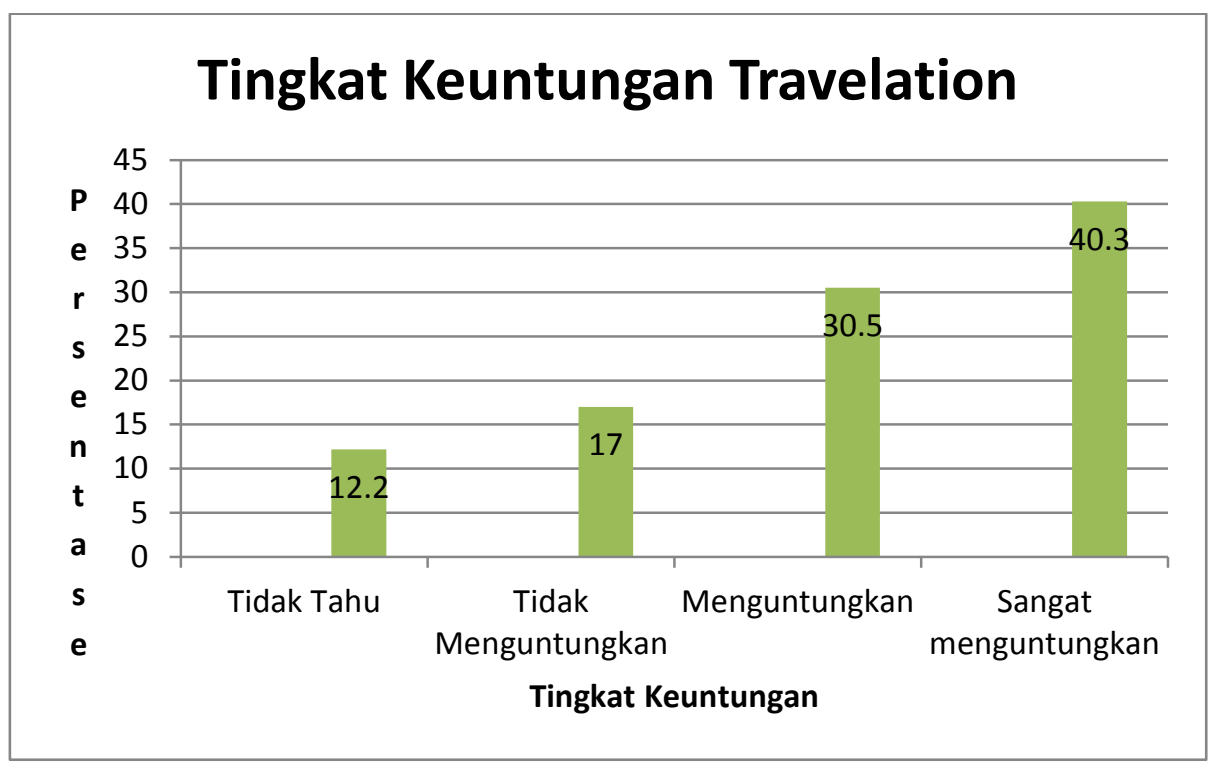

Sumber: Olahan penelitian (2021)

Gambar 2 Tingkat keuntungan relatif aplikasi travelation

Mengacu pada gambar 1 tersebut, maka dapat dikatakan bahwa apikasi Travelation memberikan tingkat keuntungan bagi para penggunanya. Hal ini menguatkan pandangan Carter \& Campbell (2011) yang menyatakan bahwa tingkat keuntungan relatif merupakan tingkat kelebihan dari suatu inovasi, apakah lebih baik dari inovasi yang ada sebelumnya atau dari hal-hal yang biasa dilakukan. Pengguna berpandangan, jika dibandingkan dengan aplikasi perjalanan sejenis, maka Travelation mempu memberikan keuntungan lebih banyak.

Faktor kesesuaian informasi merupakan sejauh mana informasi yang disajikan dalam Travelation sudah sesuai dengan nilai-nilai, pengalaman, dan kebutuhan yang diinginkan oleh pengguna (Puspita, 2019). Kesesuaian informasi dapat mempengaruhi implementasi pada Travelation karena informasi yang tidak benar akan berdampak pada rencana penerbangan. Hasil survei menunjukkan bahwa sebagian besar responden menyatakan adanya kesesuaian antara informasi travelation dengan kondisi di lapangan (sesuai 33.3\% dan sangat sesuai 40.5\%). Grafik kesesuaian informasi Travelation dapat di lihat pada Gambar 2.

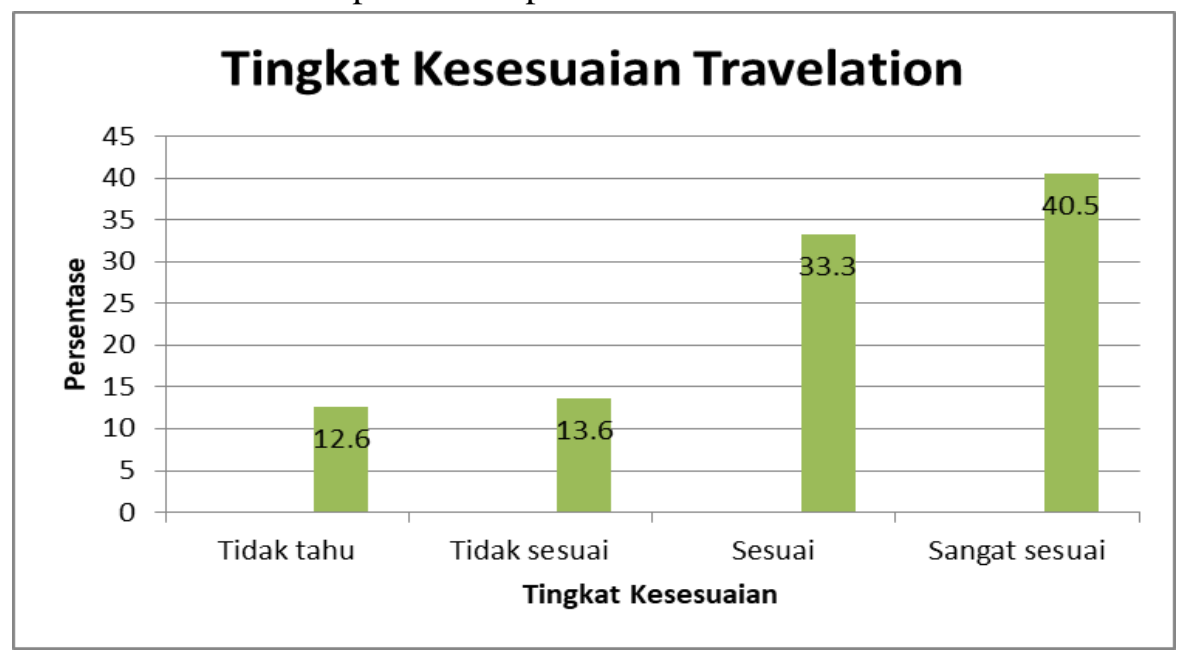

Sumber: Olahan penelitian (2021)

Gambar 3. Tingkat kesesuaian informasi Travelation 
Gambar 2 menunjukkan terdapat sebagian responden yang menyatakan bahwa informasi travelation tidak sesuai (13.6\%). Sebagian responden juga menyatakan tidak tahu (12.6\%) karena sebagian dari mereka belum menerapkan aplikasi travelation secara sepenuhnya. Kesesuaian informasi tersebut sejalan dengan pendapat Jonas-Dwyer et al., (2012) yang menyebut bahwa suatu konten aplikasi harus berisi informasi yang sesuai dengan penggunanya.

Untuk tingkat kerumitan, mayoritas responden (50.7\%) mengaku mengalami kerumitan dalam menggunakan aplikasi Travelation. Sebanyak 20.2\% responden mengaku Travelation tidak rumit, dan $15.7 \%$ responden menyatakan aplikasi Travelation sangat rumit (Gambar 3). Hal tersebut, sebagaimana dikonfirmasi (Sahputra et al., 2012) karena apilkasi di platform desktop memiliki masalah dalam hal pengaksesan, di mana aplikasi hanya dapat diakses di satu komputer, tidak dapat diakses dimana dan kapan saja. Dengan kata lain tidak fleksibel karena hanya terpasang di satu sumber daya. Hal tersebut juga dikuatkan oleh pandangan (Gunadi \& Sudaryana, 2021) yang mengatakan bahwa tingkat kerumitan aplikasi terkait dengan komplesitas atau kesulitan yang dialami oleh pengguna dalam suatu aplikasi. Aplikasi Travelation dipandang pengguna cukup rumit karena faktor adaptasi. Umumnya, adaptasi pengguna akan lebih baik jika aplikasi dibenamkan pada telepon pintar dan bukannya pada aplikasi berbasis komputer jinjing (Christensen \& Prax, 2012).

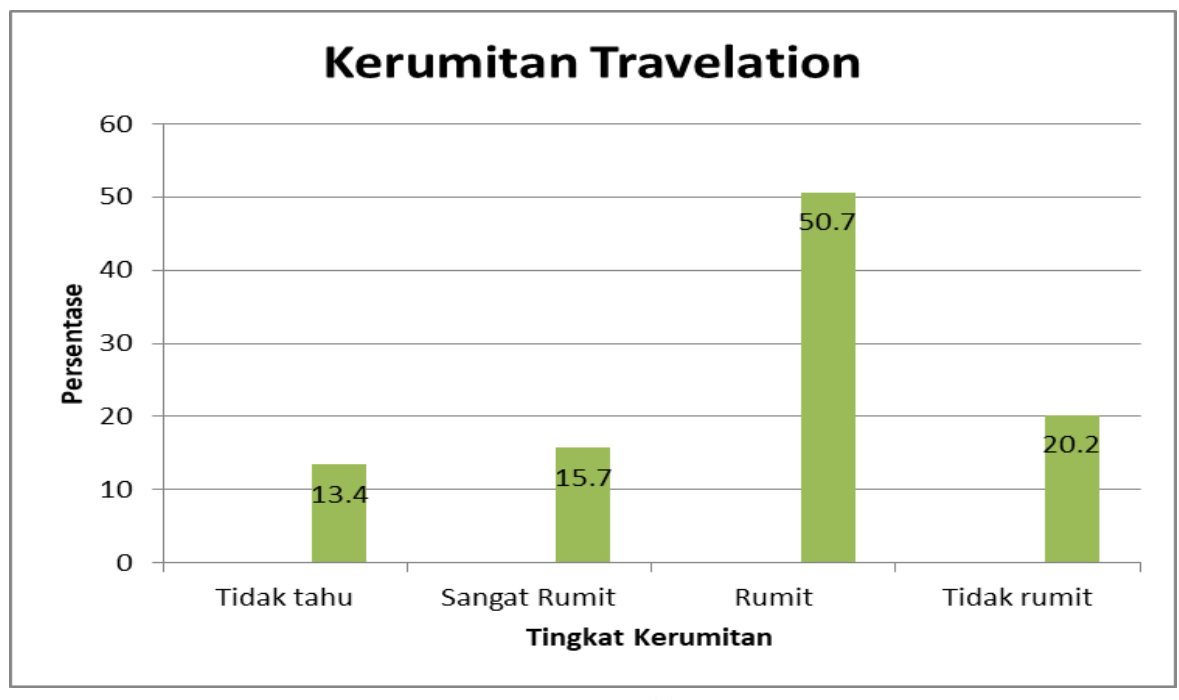

Sumber: Olahan Penelitian (2021)

Gambar 4. Tingkat kerumitan Travelation

Observabilitas menjadi indikator yang dapat mempengaruhi implementasi Travelation. Tingkat observabilitas Travelation untuk dilihat dan dikomunikasikan kepada orang lain dapat dilihat pada Gambar 4. Hasil survei menunjukkan bahwa sebagian besar responden (62.5\%) menyatakan bahwa travelation sangat mudah diobservasi atau mudah dilihat orang. Hal ini disebabkan banyak pengguna yang melihat dampak penerapan rekomendasi Travelation. Hasil ini sejalan dengan pandangan McCann et al., (2015) yang menyatakan bahwa observabilitas aplikasi adalah hasil inovasi yang dapat dilihat, diamati, dan dikomunikasikan oleh pengguna kepada orang lain. Selain itu, sebagaimana dikemukakan Lin \& Bautista (2017), meningkatkan observabilitas adalah satu-satunya cara agar suatu aplikasi dapat dicoba dan dipakai oleh pengguna lain. 


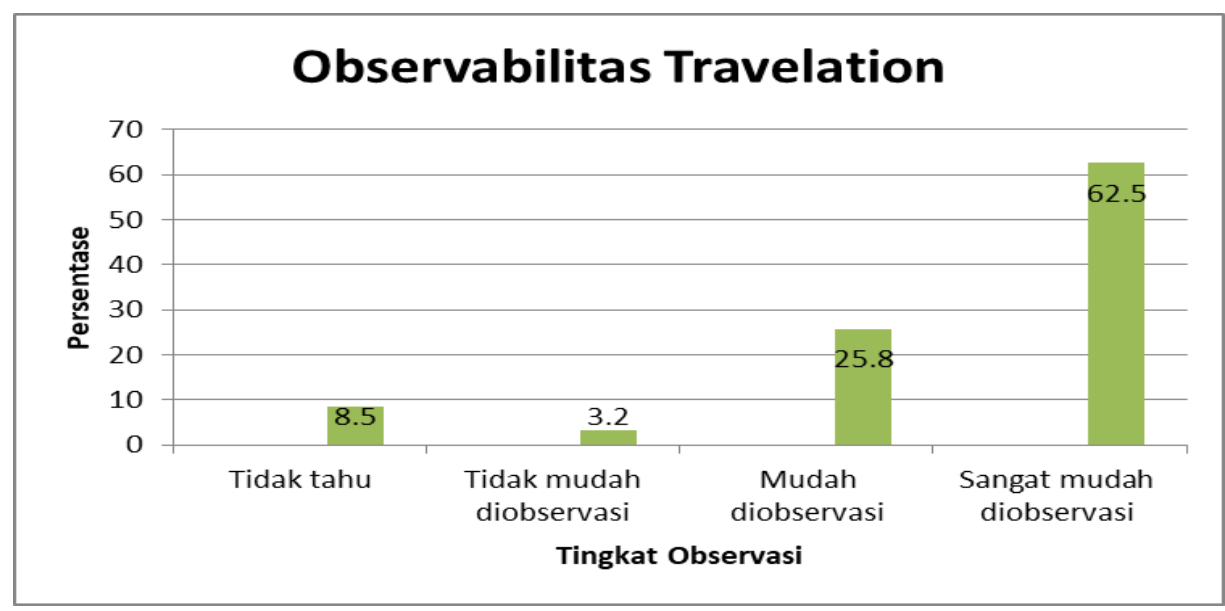

Sumber: Olahan penelitian (2021)

Gambar 5. Tingkat observabilitas Travelation

Akurasi data merupakan tingkat kebenaran dan kepercayaan dari suatu data yang terdapat pada suatu sistem informasi. Semakin akurat data yang disampaikan maka akan semakin menambah tingkat kepercayaan dan adopsi pengguna terhadap aplikasi Travelation. Hasil survei menunjukkan bahwa sebagian besar responden menyatakan data yang disampaikan oleh Travelation sudah akurat (36.1\%) dan sangat akurat (37.5\%). Hal ini mengindikasikan bahwa data yang terdapat pada Travelation selalu diperbarui sehingga menghasilkan rekomendasi konten aplikasi yang dapat diterima dengan baik dan sesuai dengan yang dibutuhkan. Grafik tingkat akurasi data Travelation dapat dilihat pada Gambar 5.

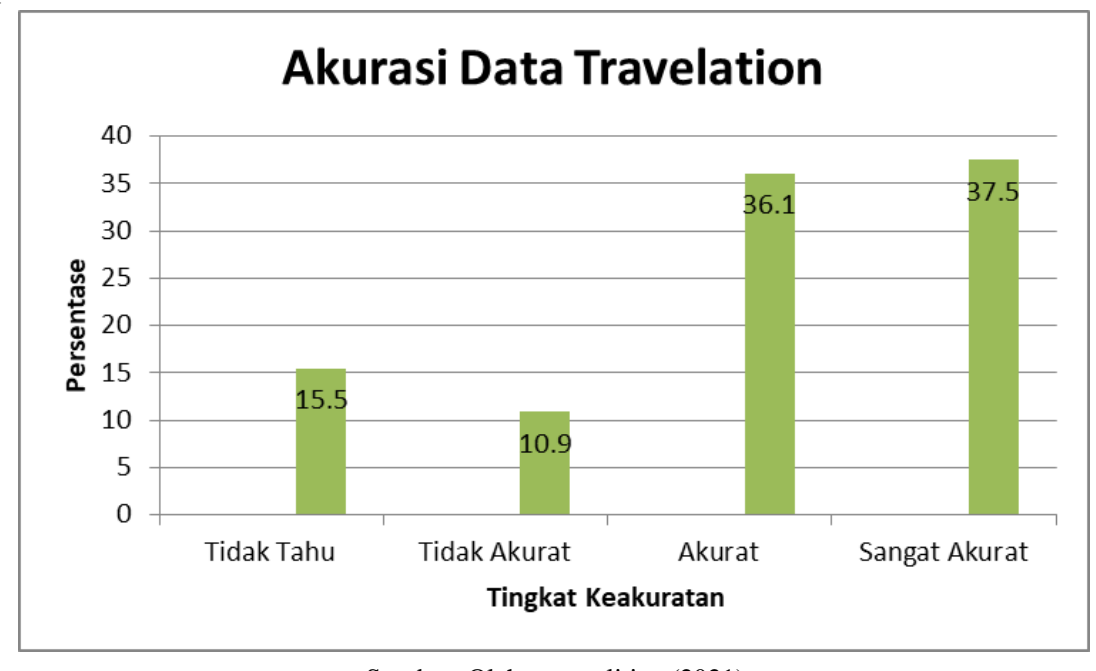

Sumber: Olahan penelitian (2021)

Gambar 6 Tingkat akurasi data Travelation

Pernyataan tingkat akurasi data rendah juga disampaikan oleh responden yang berjumlah 10,9\%. Sebagian dari kelompok ini mengungkapkan tidak pernah memperhatikan teknologi dan konten yang digunakan dalam Travelation. Hal ini dapat dipahami sebagai konsekuensi dari aplikasi Travelation yang berada di platform komputer desktop sehingga kurang populer. Tingkat akurasi data yang tinggi pada aplikasi Travelation menunjukkan bahwa aplikasi tersebut sudah memberikan data dan keperluan pengurusan dokumen dengan tepat. Hal ini sejalan dengan pandangan Bierbrier et al., (2014) yang mengemukakan bahwa akurasi data membuat kepercayaan pada aplikasi akan naik, dan pengguna yakin memakai aplikasi tersebut. 


\subsection{Pembahasan}

Aplikasi Travelation sebagai alat bantu berbasis teknologi informasi mempunyai kemampuan dapat membantu perjalanan calon pengguna. Aplikasi tersebut dapat digunakan calon penumpang pesawat untuk pengecekan dokumen penerbangan secara digital saat bepergian dalam kondisi pandemi Covid-19. Aplikasi Travelation juga terhubung dengan aplikasi e-Health Alert Card (eHAC) yang harus diisi oleh penumpang pesawat dan dicek secara digital oleh Kantor Kesehatan Pelabuhan Kementerian Kesehatan (KKP Kemenkes). Selain itu, aplikasi PeduliLindungi juga terhubung dengan Travelation.

Manfaat aplikasi Travelation tersebut dirasakan oleh responden dalam menjawab pertanyaan yang kerap disampaikan ketika akan bepergian. Hasil survei kepada responden menyatakan bahwa aplikasi Travelation bermanfaat bagi mereka dalam mengadopsi informasi seperti yang terlihat pada. Dengan manfaat tersebut, responden menerima kehadiran teknologi aplilkasi Travelation. Sebagian besar responden menyatakan aplikasi Travelation diterima karena kontennya mempunyai manfaat dan keunggulan yang sangat dirasakan calon penumpang (51.4\%) (Gambar 6). Calon penumpang dapat memanfaatkan Travelation dalam kegiatan untuk menunjang mobilitas mereka. Hasil survei menunjukkan bahwa sebagian besar responden menyatakan bahwa manfaat dari Travelationyaitu untuk menentukan waktu keberangkatan dan pemeriksaan dokumen.

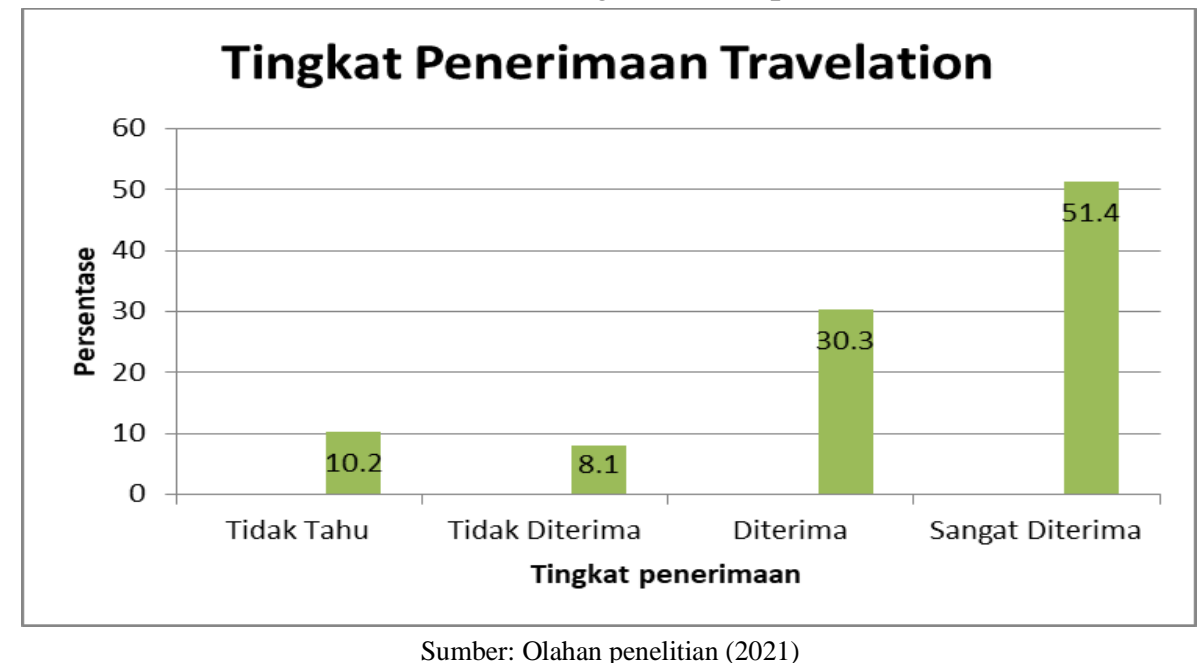

Gambar 6. Tingkat Manfaat dan Penerimaan Aplikasi Travelation

Pengujian hipotesis menggunakan uji Product Moment menunjukkan, terdapat pengaruh antara karakteristik konten dengan penerimaan pengguna pada aplikasi Travelation dengan keeratan hubungan cukup ( $\mathrm{r}=0.458$ ) (Tabel 2). Hal ini menunjukkan bahwa karakteristik konten Travelation sangat ramah pengguna dengan antarmuka yang mudah dipahami dan sesuai dengan kebutuhan pengguna yang mengadakan perjalanan sehingga menjadi daya tarik pengguna untuk menerima dan mengambil manfaat dari aplikasi Travelation.

Tabel 2. Hasil pengujian karakteristik konten dengan penerimaan pengguna

$\begin{array}{ll}\text { Pengaruh } & \text { Nilai pada } \alpha=\text { Nilai } \mathbf{r} \\ \text { antar varibel } & \mathbf{0 , 0 5}\end{array}$




\begin{tabular}{cccc}
\hline Pengaruh & Nilai & pada $\boldsymbol{\alpha}=$ & Nilai $\mathbf{r}$ \\
\hline $\mathrm{X} \rightarrow \mathrm{Y}$ & 0.002 & 0.458
\end{tabular}

Sumber: olahan penelitian (2021)

Hasil penelitian ini memperkuat pandangan Dastjerdi et al., (2019) yang menyatakan bahwa konten berpengaruh terhadap penerimaan pengguna pada suatu aplikasi yang berbasis teknologi informasi. Selain itu, dalam kerangka teori computer mediated communication (CMC), aplikasi Travelation memungkinkan penggunanya menciptakan bentuk baru realitas (Littlejohn \& Foss, 2008), yakni perjalanan yang menjadi semakin mudah. Hal yang juga tak kalah pentingnya adalah, aplikasi Travelation menjadikan interaksi manusia yang dilakukan dan difasilitasi melalui teknologi berbasis digital menjadi semakin interaktif (Spitzberg dalam Greiffenstern, 2010). Lebih lanjut menurut Arnus (2015) pola CMC, yakni komunikasi bermediasi dengan batuan internet dalam aplikasi Travelation telah menjadi gaya hidup masyarakat dan menimbulkan perubahan sebagai tanda kemajuan teknologi.

Sebagaimana dikemukakan oleh Liao \& Tsou (2009) hasil penelitian ini membuktikan pengaruh yang kuat bahwa konsumen dapat menerima teknologi sebuah aplikasi jika dipersepsikan mudah digunakan. Kemudahan itu terletak tingkat keuntungan, kesesuaian informasi, tingkat kerumitan, observabilitas, dan akurasi data. Meskipun demikian, Liao \& Tsu menggarisbawahi bahwa keterampilan komputer dari pengguna juga memegang peranan. Hal ini sesuai dengan ketersediaan aplikasi Travelation, yang memang baru ada pada platform komputer PC dan komputer jinjing.

Inovasi yang menyertai aplikasi Travelation sejalan dengan pendekatan teori difusi inovasi yang menjelaskan bagaimana inovasi menyebarluas pada suatu populasi (Min et al., 2019). Temuan penelitian ini memperkuat teori difusi inovasi tersebut. Ketika konsumen menemukan ada keuntungan, kesesuaian informasi, kerumitan, observabilitas, dan akurasi data pada suatu aplikasi, maka mereka cenderung akan memilihnya. Determinan karakteristik konten ini sekaligus mengisi kesenjangan penelitian tentang difusi inovasi pada suatu aplikasi yang sebelumnya hanya dipengaruhi kompatibitas dan pengaruh sosial (Min et al., 2019).

Kehadiran aplikasi Travelation pada dasarnya merupakan sebuah bentuk disrupsi inovasi. Agarwal \& Brem (2017) mengidentifikasi implikasi penting disrupsi inovasi bagi strategi bisnis. Perusahaan yang menawarkan disrupsi inovasi dapat bersaing dengan pemain lama, memenangkan pangsa pasar dan meraih pelanggan yang lebih banyak. Dalam kasus ini, PT Angkasa Pura 2 menawarkan aplikasi Travelation sebagai aplikasi yang memiliki kemampuan lebih baik, lebih cepat, lebih nyaman, lebih efektif dan layanan atau produk yang lebih disesuaikan. Dalam konteks masyarakat Indonesia, seperti dikemukakan (Prihanto et al., 2020), kualitas situs berbasis web/ website umumnya belum dapat memuaskan pengguna, tetapi dapat diterima masyarakat.

Analogi kualitas website tersebut dapat diterapkan di aplikasi Travelation. Kekurangan situs web aplikasi Travelation antara lain fitur yang masih sederhana, belum ada fasilitas search, dan tampilan situs web kurang familiar. Hal tersebut menguatkan temuan Rochmawati (2019) yang mengemukakan bahwa kekurangan situs web secara umum memang terletak pada tampilannya yang sederhana. Meskipun demikian, tampilan tersebut tidak mengurangi kenyamanan serta informasi yang diberikan. Kekurangan tersebut dapat ditutupi oleh aplikasi Travelation dengan meningkatkan kualitas informasi yang menjadi konten utamanya. Sebab, data dan informasi tentang penerbangan yang disediakan aplikasi Travelation kepada pengguna bermanfaat, dapat diperoleh secara daring dan real time. 


\section{PENUTUP}

Berdasarkan penelitian yang telah dilakukan, sejumlah indikator konten aplikasi Travelation mendukung penerimaan aplikasi tersebut pada penggunanya. Indikator tersebut antara lain tingkat keuntungan (total 70.8\%), kesesuaian informasi yang diberikan (73.8\%), observabilitas tinggi (62.5\%), dan akurasi data tinggi (73.6\%). Hanya saja, tingkat kerumitan aplikasi Travelation juga tinggi (50.7\%), karena aplikasi Travelation yang berbasis situs web baru memberikan tampilan optimal jika dibuka melalui komputer jinjing. Pengguna menilai manfaat konten aplikasi Travelation juga tinggi, yakni sebesar 51.4\%.

Hasil uji hipotesis menunjukkan, terdapat pengaruh antara konten aplikasi Travelation dengan penerimaan pengguna (0.002 pada taraf signifikansi 0.05 dan $\mathrm{r}=0.458$ ). Konten aplikasi Travelation mempengaruhi pengguna untuk menerima aplikasi tersebut karena memberikan manfaat kepada pengguna, berupa kemudahan mengurus dokumen penerbangan dan mengetahui jadwal penerbangan. Meskipun demikian, satu hal yang menjadi kekurangan dan disarankan dalam penelitian ini adalah pembaruan informasi pada aplikasi Travelation secara berkala. Selain itu, aplikasi Travelation juga perlu menambahkan fitur news feed berupa berita-berita terkait informasi terkini mengenai dunia penerbangan.

\section{DAFTAR PUSTAKA}

Agarwal, N., \& Brem, A. (2017). The Frugal Innovation Case of Solar-powered Automated Teller Machines (ATMs) of Vortex Engineering in India. Journal of Entrepreneurship and Innovation in Emerging Economies, 3(2), 115-126. https://doi.org/10.1177/2393957517717895

Ali, F., Terrah, A., Wu, C., Ali, L., \& Wu, H. (2021). Antecedents and consequences of user engagement in smartphone travel apps. Journal of Hospitality and Tourism Technology, 12(2), 355-371. https://doi.org/10.1108/JHTT-09-2020-0221

APJII. (2020). Buletin APJII. In Asosiasi Penyelenggara Jasa Internet Indonesia (p. 1). https://apjii.or.id/content/read/104/503/BULETIN-APJII-EDISI-74---November-2020

Arnus, S. H. (2015). Computer Mediated Communication (CMC), Pola Baru Berkomunikasi. Al-Munzir, 8(2), 275-289. https://ejournal.iainkendari.ac.id/index.php/al-munzir/article/view/744/680

Bierbrier, R., Lo, V., \& Wu, R. C. (2014). Evaluation of the accuracy of smartphone medical calculation apps. Journal of Medical Internet Research, 16(2). https://doi.org/10.2196/jmir.3062

Briz-Ponce, L., \& García-Peñalvo, F. J. (2015). An Empirical Assessment of a Technology Acceptance Model for Apps in Medical Education. Journal of Medical Systems, 39(11). https://doi.org/10.1007/s10916-015-0352-x

Byun, H., Chiu, W., \& Bae, J. S. (2018). Exploring the adoption of sports brand apps: An application of the modified technology acceptance model. International Journal of Asian Business and Information Management, 9(1), 52-65. https://doi.org/10.4018/IJABIM.2018010105

Carter, L., \& Campbell, R. (2011). The impact of trust and relative advantage on internet voting diffusion. Journal of Theoretical and Applied Electronic Commerce Research, 6(3), 28-42. https://doi.org/10.4067/S0718-18762011000300004

Cho, H., Chi, C., \& Chiu, W. (2020). Understanding sustained usage of health and fitness apps: Incorporating the technology acceptance model with the investment model. In Technology in Society (Vol. 63). Elsevier Ltd. https://doi.org/10.1016/j.techsoc.2020.101429

Christensen, C., \& Prax, P. (2012). Assemblage, adaptation and apps: Smartphones and mobile gaming. Continuит, 26(5), 731-739. https://doi.org/10.1080/10304312.2012.706461

Chuttur, M. (2009). Overview of the Technology Acceptance Model: Origins, Developments and Future Directions. Sprouts: Working Papers on Information Systems, 9(37), 1-23. https://doi.org/10.1021/jf001443p

Dastjerdi, A. M., Kaplan, S., de Abreu e Silva, J., Anker Nielsen, O., \& Camara Pereira, F. (2019). Use intention of mobility-management travel apps: The role of users goals, technophile attitude and community trust. Transportation Research Part A: Policy and Practice, 126(May), 114-135. 
https://doi.org/10.1016/j.tra.2019.06.001

Dickinson, J. E., Cherrett, T., Hibbert, J. F., Winstanley, C., Shingleton, D., Davies, N., Norgate, S., \& Speed, C. (2015). Fundamental challenges in designing a collaborative travel app. Transport Policy, 44, 28-36. https://doi.org/10.1016/j.tranpol.2015.06.013

Govender, J. P. (2013). The Adoption of Internet Banking in a Developing Economy. Journal of Economics and Behavioral Studies, 5(8), 496-504. https://doi.org/10.22610/jebs.v5i8.423

Greiffenstern, S. (2010). The influence of computers, the internet and computer-mediated communication on everyday English. Logos Verlag Berlin GmbH.

Gunadi, G., \& Sudaryana, I. K. (2021). Analisa tingkat penerimaan aplikasi Scratch menggunakan technology acceptance model (TAM). Infotech: Journal of Technology Information, 7(1), 7-18.

Gupta, A., Dogra, N., \& George, B. (2018). What determines tourist adoption of smartphone apps? Journal of Hospitality and Tourism Technology, 9(1), 50-64. https://doi.org/10.1108/jhtt-02-2017-0013

Hassan, M., Kouser, R., Abbas, S. S., \& Azeem, M. (2014). Consumer Attitudes and Intentions to Adopt Smartphone Apps: Case of Business Students. Pakistan Journal of Commerce and Social Sciences, 8(3), 763-779.

Ispriandina, A., \& Sutisna, M. (2019). Faktor-Faktor Penerimaan Teknologi Yang Memengaruhi Intensi Kontinuitas Penggunaan Mobile Wallet Di Kota Bandung. Prosiding Industrial Research Workshop and National Seminar, 10(1), 1046-1055. https://jurnal.polban.ac.id/ojs3.1.2/proceeding/article/view/1462

Jonas-Dwyer, D. R. D., Clark, C., Celenza, A., \& Siddiqui, Z. S. (2012). Evaluating apps for learning and teaching. International Journal of Emerging Technologies in Learning, 7(1), 54-57. https://doi.org/10.3991/ijet.v7i1.1901

Kamel Boulos, M. N., Brewer, A. C., Karimkhani, C., Buller, D. B., \& Dellavalle, R. P. (2014). Mobile medical and health apps: state of the art, concerns, regulatory control and certification. Online Journal of Public Health Informatics, 5(3), 1-23. https://doi.org/10.5210/ojphi.v5i3.4814

Karomah, Y. P. (2020). Persepsi Petani terhadap Aplikasi RegoPantes sebagai Penunjang Program Petani Go Online dalam Penggunaannya untuk Media Pemasaran Hasil Panen di Desa Wonokerso Kabupaten Batang. 4(1), 348-357.

Kim (Sunny), J. (2016). An extended technology acceptance model in behavioral intention toward hotel tablet apps with moderating effects of gender and age. In International Journal of Contemporary Hospitality Management (Vol. 28, Issue 8). http://dx.doi.org/10.1108/IJCHM-06-2015-0289

Kim, Y., \& Kim, H. (2020). Usability Evaluation and Improvements of Mobile Travel Apps. International Journal of Internet, Broadcasting and ..., 12(1), 27-36. https://www.koreascience.or.kr/article/JAKO202007752705985.page

Lee, S.-J., \& Jing, D. (2015). Use Intentions of Mobile Tour Apps through Expansion of the Technology Acceptance Model. Journal of Distribution Science, 13(10), 135-142. https://doi.org/10.15722/jds.13.10.201510.135

Liao, C. H., \& Tsou, C. W. (2009). User acceptance of computer-mediated communication: The SkypeOut case. Expert Systems with Applications, 36(3 PART 1), 4595-4603. https://doi.org/10.1016/j.eswa.2008.05.015

Lin, T. T. C., \& Bautista, J. R. (2017). Understanding the Relationships between mHealth Apps' Characteristics, Trialability, and mHealth Literacy. Journal of Health Communication, 22(4), 346-354. https://doi.org/10.1080/10810730.2017.1296508

Littlejohn, S. W., \& Foss, K. A. (2008). Theories of Human Communication (9th ed.). Thomson Wadsworth.

Lu, J., Mao, Z., Wang, M., \& Hu, L. (2015). Goodbye maps, hello apps? Exploring the influential determinants of travel app adoption. Current Issues in Tourism, 18(11), 1059-1079. https://doi.org/10.1080/13683500.2015.1043248

Mahmudah, D. (2018). Persepsi Aparat Pemerintah Kota Jambi terhadap Kegunaan dan Kemudahan Penggunaan Media Pengaduan Berbasis Aplikasi. Jurnal Studi Komunikasi Dan Media, 22(2), 123. https://doi.org/10.31445/jskm.2018.220203

Marangunić, N., \& Granić, A. (2015). Technology acceptance model: a literature review from 1986 to 2013. Universal Access in the Information Society, 14(1), 81-95. https://doi.org/10.1007/s10209-014-0348-1

McCann, L., Gedikoglu, H., Broz, B., Lory, J., \& Massey, R. (2015). Effects of observability and complexity on farmers' adoption of environmental practices. Journal of Environmental Planning and Management, 58(8), 1346-1362. https://doi.org/10.1080/09640568.2014.924911

Min, S., So, K. K. F., \& Jeong, M. (2019). Consumer adoption of the Uber mobile application: Insights from diffusion of innovation theory and technology acceptance model. Journal of Travel and Tourism Marketing, 36(7), 770-783. https://doi.org/10.1080/10548408.2018.1507866

Mugo, D., Njagi, K., Chemwei, B., \& Motanya, J. (2017). The Technology Acceptance Model (TAM) and its 
Application to the Utilization of Mobile Learning Technologies. British Journal of Mathematics \& Computer Science, 20(4), 1-8. https://doi.org/10.9734/bjmcs/2017/29015

Nugroho, A. H., Bakar, A., \& Ali, A. (2017). Analysis of Technology Acceptance Model: Case Study of Traveloka Arthatama. Journal of Business Management and Accounting, 1(1), 27-34.

Park, Y. S., Konge, L., \& Artino, A. R. (2020). The Positivism Paradigm of Research. Academic Medicine, 95(5), 690-694. https://doi.org/10.1097/ACM.0000000000003093

Prihanto, I. G., Riyanto, B., Gunawan, H., Kuntjahyowati, E., Haris, I., \& Ramadhan, A. A. (2020). Pengaruh kualitas website Lembaga Penerbangan dan Antariksa Nasional (LAPAN) terhadap kualitas pengguna. Jurnal Studi Komunikasi Dan Media, 4, 153-168.

Primawati, A. (2015). Kajian Kesiapan dan Penerimaan Teknologi Aplikasi Google Documents untuk Penyelesaian Tugas Kelompok Siswa. Seminar Nasional Cendekiawan, 2010, 1-11.

Priyono, A. (2017). Analisis pengaruh trust dan risk dalam penerimaan teknologi dompet elektronik Go-Pay. Jurnal Siasat Bisnis, 21(1), 88-106. https://doi.org/10.20885/jsb.vol21.iss1.art6

Puspita, Y. C. (2019). Penggunaan Digital Payment Pada Aplikasi Ovo. Jurnal Manajemen Informatika, 09(02), 121-128. $\quad$ https://jurnalmahasiswa.unesa.ac.id/index.php/jurnal-manajemeninformatika/article/view/29471/26993

Rochmawati, I. (2019). Analisis User Interface Situs Web iwearup.com. Visualita, 7(2), 14. https://ojs.unikom.ac.id/index.php/visualita/article/download/1459/1006

Rogers, E. M. (1995). Diffusion of Innovations (4th ed.). The Free Press.

Sahputra, A. O., Susilo, A., \& Nurhastuti, T. (2012). Aplikasi photo editor berbasis web (Picfiix) sebagai alternatif aplikasi berbasis desktop. Prosiding Seminar Nasional Aplikasi Sains \& Teknologi (SNAST) Periode III, November, 1-8.

Styawan, D. A. (2021). Pandemi Covid-19 Dalam Perspektif Demografi. Seminar Nasional Official Statistics, 2020(1), 182-189. https://doi.org/10.34123/semnasoffstat.v2020i1.716

Sugiharto, T., Suhendra, S., Hermana, B., \& Suhendra, A. (2007). Model Adopsi E-Business oleh Pengusaha Kecil: Metode Pengukuran dengan Webstatistic dan Self Reported. Proc. Seminar Nasional Teknologi (SNT 2007).

Taherdoost, H. (2018). A review of technology acceptance and adoption models and theories. Procedia Manufacturing, 22, 960-967. https://doi.org/10.1016/j.promfg.2018.03.137

Utomo, Y., \& Abdul Jumali, M. (2021). Model Penerimaan Teknologi Aplikasi Pemasaran Pada Koperasi Usaha Wanita Dukuh Menanggal Surabaya. Waktu, 19(01), 22-30. https://doi.org/10.36456/waktu.v19i01.3242

Wu, R., \& Lee, J. H. (2017). The use intention of mobile travel apps by Korea-visiting Chinese tourists. Journal of Distribution Science, 15(5), 53-64. https://doi.org/10.15722/jds.15.5.201705.53

Yulistyanti, D. (2016). Kajian Penerimaan Aplikasi Dropbox Dalam Pekerjaan Kelompok Siswa: Studi Kasus Smk Setia Negara Depok. Simetris: Jurnal Teknik Mesin, Elektro Dan Ilmu Komputer, 7(1), 1528. https://doi.org/10.24176/simet.v7i1.484 